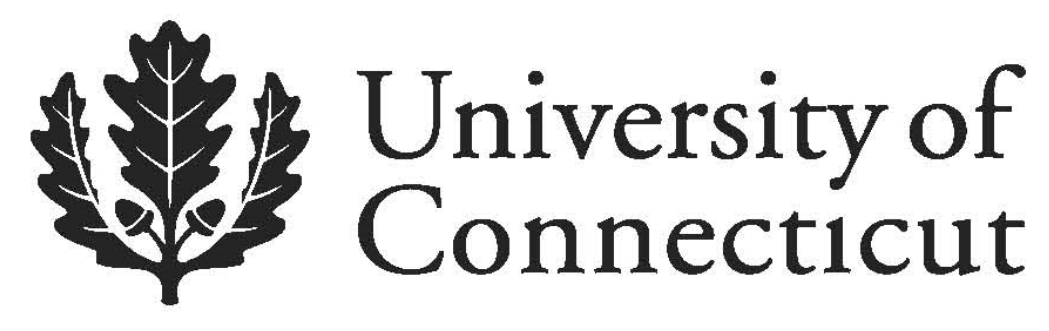

Department of Economics Working Paper Series

\title{
The Color of Law: An Economic Theory of Legal Boundaries
}

Thomas J. Miceli

University of Connecticut

Working Paper 2013-17

July 2013

365 Fairfield Way, Unit 1063

Storrs, CT 06269-1063

Phone: (860) 486-3022

Fax: (860) 486-4463

http://www.econ.uconn.edu/

This working paper is indexed on RePEc, http://repec.org 


\title{
The Color of Law: An Economic Theory of Legal Boundaries
}

\author{
by \\ Thomas J. Miceli
Professor, Department of Economics
365 Fairfield Way
University of Connecticut
Storrs, CT 06269
Ph: (860) 486-5810
Fax: (860) 486-4463
e-mail: Thomas.Miceli@UConn.edu

\begin{abstract}
This paper presents an economic theory of property, tort, and contract law based on the goal of efficiently governing economic exchange relationships. In the theory, legal boundaries emerge endogenously in response to exogenous differences in the nature of the underlying transaction concerning the possible existence of unforeseen or non-contractible contingencies, and/or the desire of one of the parties to make non-salvageable investments prior to trade. The analysis asks whether, in this context, the transaction is best governed by property, tort, or contract principles. The conclusions are illustrated by a discussion of several cases that occupy the "boundaries" between the various areas.
\end{abstract}

Key words: Property, torts, contracts, legal boundaries

JEL codes: K10, K11, K12, K13

July 2013 


\section{The Color of Law: An Economic Theory of Legal Boundaries}

\section{Introduction}

One of the strengths of the economic analysis of law is its ability to unify disparate areas of law within a common theoretical framework. This approach is epitomized by Cooter's (1985) use of the model of precaution, first developed by Brown (1973) in the context of accident law, to explain various doctrines in torts, contracts, and property. Cooter's unifying effort might be called a "top-down" approach because it takes as given the demarcations between the fields, and then shows that doctrines within those fields can be understood within the context of Brown's model. The approach in this paper is somewhat different in that it takes as its starting point an exchange relationship between two parties. Law then emerges as the means of governing the exchange (enforcing agreements and resolving disputes), with formal legal boundaries emerging endogenously in response to exogenous variations in the nature of the underlying exchange. In this sense, the theory is "bottom-up."

This perspective is in the spirit of Calabresi and Melamed's (1972) classic analysis of the boundary between property and tort law based on the distinction between property rules and liability rules. ${ }^{1}$ In their theory, property rules form the basis for property law and represent the manner in which legal entitlements, or rights, are protected against unwanted infringements. In particular, entitlements protected by property rules can only be acquired from their owners by bargaining, and so property rules form the basis for market (consensual) exchange. Property rules also provide legal protection for investments in property by ensuring that the owner is the

\footnotetext{
${ }^{1}$ On this distinction, also see Polinsky (1980), Ayres and Talley (1995), and Kaplow and Shavell (1996).
} 
sole beneficiary of the returns from those investments. In both of these ways, property rules promote the creation of economic value.

Liability rules, in contrast, allow unwanted seizures of entitlements from their owners, while obligating the acquirer to pay monetary compensation to the owner for the resulting loss. Exchanges of entitlements under liability rules are thus involuntary, but may nevertheless enhance value if high bargaining costs would have prevented otherwise efficient exchanges from taking place. In this way, legal exchange replaces market exchange when the market fails. The cost of involuntariness is that the determination of the price of the transaction falls to the court, which is susceptible to error, thus creating the possibility that some efficient exchanges may be foregone (if the price is set too high), while others may inefficiently go forward (if the price is set too low).

In the Calabresi-Melamed framework, the boundary between tort and property law emerges endogenously based on which of the two rules maximizes the value of the transaction in question based on the characteristics of the exchange environment. Specifically, property rules are preferred when transaction costs are low, thus encouraging voluntary (market) exchange, and liability rules are preferred when transaction cost are high, thus requiring court-ordered (legal) exchange. The positive economic theory of law asserts that the boundary between tort and property law has largely evolved to reflect this choice (Posner, 2003).

If property rules are the basis for property law, and liability rules are the basis for tort law, where does contract law fit into this framework? Contracts represent legally enforceable promises between two parties, and in this sense, resemble consensual exchange under property rules. It is when the parties to a contract encounter an unforeseen (or unprepared-for) contingency that the difference arises. To see how, consider a contract that two parties negotiate, 
which obligates the holder of an entitlement (the promisor) to transfer it to another party (the promisee) at some future date in return for a monetary payment. The exchange, if it takes place, is consensual and so is effectively governed by a property rule. But if, when the date of transfer arrives, the promisor decides not to go through with it, for whatever reason, the promisee can seek monetary compensation (damages) for the lost value of performance, but generally cannot compel the promisor to perform. In this sense, the promisee's legal right to performance, as negotiated in the original agreement, is protected by a liability rule, not a property rule. ${ }^{2}$

The preceding discussion suggests that property, tort, and contract law can be characterized in terms of the fundamental building blocks of property rules and liability rules. One way to think about the relationship among them is that property law and tort law lie at two ends of a spectrum, reflecting pure property rules and pure liability rules, respectively, with contract law lying between them. A better schema is to think of property, torts, and contracts as representing three points on a circle, like the three primary colors on a "color wheel," as illustrated in Figure 1, with each area "shading" into the other around the wheel. The next section lays out the theoretical framework that will be used to flesh out this image. Section 3 then develops a formal model of the situation and examines the specific factors that determine where the boundaries are (or should be) between the "primary" areas of law. Section 4 applies the conclusions to some sample cases by way of illustrating the argument, focusing on cases at the boundaries between the various areas, and Section 5 concludes.

[Figure 1 here]

\section{Theoretical Framework}

\footnotetext{
${ }^{2}$ Under a specific performance remedy, the promisee can ask the court to enforce the contract as written, in effect giving him or her property rule protection of the right to performance. See the discussion in Section 3.6 below.
} 
The analysis will be based on a hypothetical transaction in which a buyer seeks to acquire an entitlement from its current owner, where the entitlement, whether it be land, the right to pollute, or some other valuable asset or right, is a necessary input that allows the buyer to undertake some productive activity. In preparation for the exchange, the buyer may also be able to make a non-salvageable investment that enhances the value of the activity. ${ }^{3}$ At the time the buyer must invest, however, the opportunity cost of the input to the seller may be unknown, in which case the buyer has to make his investment under uncertainty. When the cost is revealed, the parties then have to decide whether or not to go ahead with the transaction. Efficiency in this case concerns both the amount of the initial investment, and the decision of whether or not to complete the transaction once costs are known.

Before proceeding with the formal model, we first consider, in a stylized way, how each of the three primary areas of law would govern the above transaction.

\subsection{Property}

The conventional understanding of private property corresponds to the protection of entitlements by property rules. Under ideal conditions, property rules promote efficient investment in property by ensuring that owners have exclusive claims to any profits from the property so protected, and also that all efficient transfers of the property occur by Coasian bargaining. Consent is therefore crucial in ensuring mutual gains, but in the context of the hypothetical transaction, consent is a double-edged sword because it can give rise to a hold up problem after the buyer has made his preparatory investment.

Specifically, once the investment is in place, assuming that it is at least partially nonsalvageable, the investor is in a vulnerable bargaining position because the owner of the

\footnotetext{
${ }^{3}$ Of course, it is possible that both parties might want to make preparatory investments (see, for example Bolton and Dewatripont (2005, pp. 560-563)). I adopt the simpler unilateral investment formulation here to keep the model simple.
} 
entitlement, under property rule protection, can attempt to capture some of the expected gain from the investment by threatening to back out of the transaction. Anticipating this, the investor will tend to underinvest relative to the efficient level in an effort to reduce his exposure to such a threat. Thus, even if the transaction goes through, it results in a smaller joint gain than would have been attained in the absence of the holdup problem. This sort of ex post bargaining under a property rule in the presence of non-salvageable investments is therefore an important source of inefficiency in the hypothetical transaction. Thus, while property rules ensure that any transactions that take place are efficient (assuming costless bargaining), they may lead to underinvestment in value-enhancing reliance because of the holdup threat.

\subsection{Torts}

Conventionally, tort law governs the assignment of liability for "accidental" harms and thus relies entirely on the use of liability rules. Most true torts are involuntary in the sense that the "transaction" in question (for example, the imposition of property or personal damage) is accidental, and so there is no practical way of bargaining prior to the exchange. In this case, a liability rule is the only option for determining the "price" of the exchange in settings involving accidental (unanticipated) harm.

However, liability rules can also be used in situations where the harm-creating activity is anticipated (as in the case of, for example, a polluting factory or a dangerous product), and so bargaining is theoretically possible, but the cost of arranging the transactions needed to transfer the entitlement(s) in question is so high as to make bargaining infeasible or undesirable. (The threat of a holdup problem as described in the previous section is one such cost of bargaining; a large number of entitlement holders is another.) In comparison, the use of a liability rule to protect the seller's entitlement avoids these costs because the buyer does not need to bargain 
with the holder after making his investment; he can simply take it and pay a price set by the court to reflect the cost incurred by the holder. As a result, the buyer will have no reservations about investing efficiently prior to the exchange.

Liability rules entail two offsetting costs, however. The first, which we will largely ignore, are the litigation costs involved in using the legal system to arrange the terms of exchange. (This is the counterpart to bargaining costs under property rules.) The second, which will be our focus, is the risk of legal error arising from the court's need to measure the loss suffered by the holder of the entitlement. In cases where the entitlement is real property, the usual measure of damages is the fair market value of the property, but in many cases this value will systematically underestimate the true opportunity cost to the owner. For example, many owners attach subjective value to their property, which represents the amount that they would accept in a consensual transaction above its market value. ${ }^{4}$ And in cases where the asset in question is not traded in the market, like the right to be free from personal injury or the valuation of an environmental good, the situation is worse because no ready measure of value is available. Thus, courts are left to come up with the best estimate available. For these reasons, use of liability rules create the risk of inaccurate measures of the true value of the asset in question, resulting in the possibility of too many or too few transfers occurring from an efficiency point of view.

In comparison to property rules, liability rules therefore have the advantage of avoiding the holdup threat because bargaining is not possible, but they have the disadvantage of relying on the court to set the price of exchange. The efficient choice therefore depends on which dimension is more important in a given context.

\subsection{Contracts}

${ }^{4}$ See, for example, Fischel (1995a), Ketsch and Borcherding (1979), and Miceli (2011a, Chapter 3). 
Contracts involve voluntary transfers of entitlements, suggesting that they are governed by property rules. The advantage of using a contract (as opposed to a spot transaction), however, is the ability of the parties to pre-commit to the price before any investments are made, thereby avoiding the holdup problem. In other words, the parties negotiate the price of the transfer before the buyer makes any non-salvageable investments. At the same time, however, the price may have to be set before all relevant information (such as the seller's opportunity cost) is known. Then, once that information is revealed, the parties have to decide whether or not to go ahead with the transaction. In some cases, it will be efficient to cancel performance or to renegotiate the original contract. The distinguishing feature of contract law is that any decision not to honor the terms of the original contract represents a breach of that agreement which the victim of the breach can legally enforce. When the legal remedy is money damages (a liability rule), the seller is free to break the contract provided he or she is willing to pay the buyer's dollar losses resulting from the seller's failure to perform according to the terms of the original agreement. In other words, in the event of breach, the buyer's right to performance as originally negotiated by the parties is protected by a liability rule. In this sense, contract law contains elements of both property and torts—-that is, it involves a consensual agreement that is enforced by a liability rule in the event of breach, where the amount of damages depends on the terms of the original agreement.

In some limited circumstances, the court can order specific performance of the contract, which would require the seller, upon learning his or her cost of performance, to negotiate with the buyer for a buy-out. ${ }^{5}$ Under this remedy, the buyer's right to performance is protected by a

\footnotetext{
${ }^{5}$ See Ulen (1984) and Friedmann (1989), who argue for wider use of specific performance.
} 
property rule. ${ }^{6}$ (Specific performance is obviously unavailable when performance is impossible. $)^{7}$ In that case, contract law really is a variant of property law because the seller, if he wants to breach, must negotiate buy-out price with the buyer. Consequently, a version of the original holdup threat re-emerges. The offsetting benefit is that the court is not involved in setting the price of the exchange, and so there is no risk of legal error.

To be more specific, note that specific performance only differs from a property rule as described above in terms of the timing of the seller's promise of performance relative to the buyer's investment. Under a pure property rule regime, recall, the buyer effectively acquired the entitlement to take delivery of the input only after he invested, which is what made him susceptible to the holdup problem. In other words, the price of the transfer was negotiated after the buyer's investment was in place. Under contract law with a specific performance remedy for breach, in contrast, the buyer acquires the right to delivery of the input before he invests. In this way, he avoids the holdup problem if, after the seller realizes the cost of performance, the parties go ahead with the transaction at the original price. However, if the cost of performance turns out to be so high that the seller is unwilling to deliver the entitlement at the original price, the parties can negotiate a new price, but given that the buyer holds a legally enforceable right to performance by virtue of the contract, that price will necessarily depend on the original price. And although this should result in an efficient decision regarding performance (assuming Coasian bargaining), it turns out that the buyer, in anticipation of this transaction, will overinvest in the non-salvageable input. This inefficiency is the mirror of the holdup problem under property law.

\subsection{Summary}

\footnotetext{
${ }^{6}$ In practice, money damage is the preferred remedy, with specific performance being limited to cases involving land, or other goods for which money damages is not a good substitute for performance.

${ }^{7}$ On impossibility in contract law, see Posner and Rosenfield (1977) and White (1988).
} 
The preceding discussion suggests the following stylized distinctions among the basic areas of property, torts, and contracts. Under property law, the parties to a transaction set the terms of the transaction entirely through bargaining, with the only role of the court being to enforce whatever bargains they arrange and at whatever point in time. This bargaining guarantees efficient exchange, but may inhibit reliance investments due to the holdup threat if bargaining is possible after the investment is in place. The timing of bargaining is therefore crucial in terms of evaluating the efficiency of a pure property regime.

In contrast, under tort law, the court sets the terms of any transaction, whether because the parties are physically unable to do so, or because high transaction costs prevent it. And while this removes the holdup threat because no bargaining takes place, it makes the efficiency of the exchange dependent on the ability of the court to set the correct damage amount. A tort (liability rule) approach therefore potentially trades off the risk of a holdup problem against the possibility of legal error.

Finally, under contract law the parties are able to negotiate an initial price for the transaction, which the court stands ready to enforce if and when the parties become involved in a dispute. The distinguishing feature of contract law relative to property law, therefore, is the ability of the parties to pre-commit to a price, which the court will enforce in the event of a dispute, while the distinguishing feature of contract law relative to tort law is that the courtimposed remedy, even though it is usually a liability rule, depends on the initially negotiated price. When performance at the initial price is highly likely, the outcome under contract law approaches the efficient outcome. However, when breach is a strong possibility due to unforeseeable events, the problems of inefficient reliance and court mis-measurement are both potentially present. 
The formal doctrines in the various areas of law may not always coincide perfectly with the distinctions implied by this simple framework, especially in cases where one area shades into another. Still the hope is that the basic insights can contribute to a fuller understanding of how the law promotes efficient economic exchange and investment, either as a supplement to, or a substitute for, the market mechanism.

\section{The Formal Model}

This section formalizes the preceding discussion by developing a mathematical model of the hypothetical transaction between the holder of an entitlement and a would-be buyer who will then use the entitlement as an input in some productive activity. In anticipation of the transaction, the buyer can make a non-salvageable reliance investment that enhances the value of the exchange. To be concrete, consider the owner of a polluting factory who first builds his plant, and then must acquire pollution rights from neighboring landowners. The transfer of the entitlement may be voluntary or involuntary, depending on the technological feasibility of bargaining as well as the legal setting in which the exchange would occur. The objective of the model is to compare different legal settings to determine the most efficient one for governing the transaction.

The details of the model are as follows. A particular legal entitlement, or right, is currently held by one party, the owner/seller, but is sought by another party, the buyer, to be used as an input for some productive activity. Prior to acquiring the entitlement, the buyer makes a non-salvageable investment, $x$, that will yield a gross value $V(x)$ in the event that the transaction goes forward, where $V^{\prime}>0, V^{\prime}<0$. One can interpret $x$ as the scale of the buyer's planned activity-for example, it could represent the size of his plant. At some time after $x$ is in place, 
the seller's opportunity cost of surrendering the entitlement is realized. Let this cost be $C$, which has the distribution function $F(C)$ and density $f \equiv F^{\prime}>0 .{ }^{8}$

As noted, the timing of decisions is important. The fact that the buyer must invest $x$ prior to the realization of the seller's cost reflects the idea that in many settings, some preparatory investments must be made before it is known whether transfer of the entitlement is socially desirable (reflecting, for example, cost uncertainty). Alternatively, it could represent the inability of the parties to contract over the price of the input. This will be especially true of inputs like pollution rights that are not ordinarily traded on the market.

\subsection{The Social Optimum}

Efficiency in this setting involves both the initial investment and the actual exchange of the input. Examining these decisions in reverse sequence, we first note that the transfer of the input from the owner to the acquirer is efficient if and only if $V(x) \geq C$ for any choice of $x$ by the buyer and realization of $C$ by the seller. That is, the acquirer should obtain the entitlement if and only if he values it more, given his initial investment, than does the owner.

Given this condition for an efficient transaction, the buyer's prior choice of $x$ solves

$$
\max \int_{0}^{V(x)}(V(x)-C) f(C) d C-x
$$

The resulting first-order condition defining $x^{*}$ is

$$
F(V(x)) V^{\prime}(x)-1=0
$$

where the first term is the expected marginal benefit of the investment, and the second is the marginal cost $(=\$ 1)$. Using these conditions as a benchmark, we now consider the outcomes under the various legal settings, as characterized above.

\footnotetext{
${ }^{8}$ For simplicity, we will treat the entitlement in question (the right to pollute) as a single item that is independent of the scale of the buyer's activity. For example, the right to pollute is unrestricted rather than being dependent on the size of the plant. This assumption, while somewhat limiting, simplifies the model without affecting the qualitative conclusions.
} 


\subsection{Property Law}

Under property law, recall, exchange of the entitlement occurs on a voluntary basis under a property rule. We will assume that transaction costs are zero, so that once the buyer has invested $x$ and the seller realizes $C$, the transfer will occur if and only if $V(x) \geq C$. Thus, assuming zero bargaining costs, all efficient transactions occur, given $x$ and $C$, with the price being determined by generalized Nash bargaining. Thus, $P$ is given by

$$
P=(1-\alpha) V(x)+\alpha C \text {. }
$$

where $\alpha$ as the measure of the buyer's bargaining power. Anticipating this, the buyer will choose $x$ to

$$
\max \int_{0}^{V(x)}(V(x)-P) f(C) d C-x
$$

Substituting for $P$ from (3) and setting the derivative with respect to $x$ equal to zero yields the first-order condition for the buyer's optimal investment, denoted $x_{P}$ :

$$
F(V(x)) \alpha V^{\prime}(x)-1=0 .
$$

Comparing this condition to (2) shows that $x_{P}<x *$ as $\alpha<1$. This represents the inefficiency associated with the holdup problem. Specifically, the buyer underinvests in his activity because he expects the seller to be able to capture a share (given $\alpha<1$ ) of the expected gains in subsequent bargaining over the input. ${ }^{9}$

\subsection{Tort Law}

Consider next the case of exchange under tort law; that is, under a pure liability rule. As noted, this will occur by necessity in those situations where bargaining prior to exchange is not possible (as in the case of accidents), but it can also occur when acquirers are not legally required

\footnotetext{
${ }^{9}$ For general discussions of the holdup problem, see Williamson (1975), Klein, Crawford and Alchian (1978), Goldberg (1985), and Miceli and Segerson (2012a).
} 
to bargain before taking the entitlement (as in the case of a polluting firm). Either way, the court sets the terms of exchange after the fact by awarding the entitlement owner damages for her loss. Efficiency of the exchange therefore depends on the court's ability to accurately measure the owner's realized opportunity cost, $C$. It is often argued that courts systematically underestimate this cost because they ignore, or are not able to measure, the so-called "subjective value" that owners may attach to their property. Again, this is most likely in cases where the input is a nontraded good, though it is also important in cases involving land. To capture this possibility, we let ex post damages be $D=\varphi C$, where $\varphi \leq 1$. It will be apparent, however, that the results generalize to cases where the court overestimates damages as well.

Given this measure of damages, the acquirer will take the entitlement if and only if $V(x) \geq \varphi C$, which entails too much acquisition if $\varphi<1$ for any prior choice of $x$. Anticipating this, the acquirer will choose $x$ to

$$
\max \int_{0}^{V(x) / \varphi}(V(x)-\varphi C) f(C) d C-x
$$

The resulting first-order condition, which defines $x_{T}$, is

$$
F(V(x) / \varphi) V^{\prime}(x)-1=0 .
$$

Thus, $x_{T}>x *$ when $\varphi<1$. The buyer therefore overinvests relative to the social optimum because the probability that he will go ahead with the transaction is inefficiently high as a result of the court's underestimate of the seller's opportunity cost of losing the entitlement. (Obviously, the reverse would be true if the court overvalued the entitlement.) In the context of an "accidental" transfer, the acquirer's overinvestment can be interpreted as an inefficiently high activity level, which further increases the probability of a transfer of the entitlement (i.e., imposition of damages).

\subsection{Contract Law Under Money Damages}


As argued above, under contract law with a money damages remedy, the parties are able to enter into an initial agreement, before $x$ is invested, that specifies the terms of a future exchange of the entitlement (for example, performance date and price), but the seller retains the right to back out of the exchange by paying damages as set by the court. In other words, a property rule governs the acquirer's purchase of a future right to the entitlement from the seller on mutually acceptable terms (i.e., the court enforces the initially negotiated price), but the buyer's right to complete the purchase is protected by a liability rule, which means that the seller, at his will, can seek a new price set by the court. In this sense, contract law is a hybrid of property and tort law.

Suppose that the initial contract between the parties calls for transfer of the entitlement at a future date for a price equal to $P_{0}$. (Presumably, this price reflects the parties' expectations about the gains from transacting at this point in time, as well as their bargaining abilities.) This agreement establishes a legally enforceable entitlement point, representing the buyer's right to performance. Relying on this promise, the buyer can invest $x$ (as described below), yielding an "expectation interest" of $V(x)-P_{0}$. However, because the right to performance is only protected by a liability rule, the seller can back out of the transaction without the buyer's consent by paying damages. Here is where contract law differs from property law. Under property law (or a specific performance remedy, to be described below), the seller would not be able to breach without first obtaining the buyer's permission; that is, by renegotiating the contract.

If, under the liability rule, courts could measure damages accurately, the appropriate damage measure in the event of breach would be expectation damages, or $D=V(x)-P_{0}$, for any $x$, which is the full value of the acquirer's expectation interest. As in the case of tort law, however, courts may mis-measure this value, especially if $V(x)$ includes a subjective, or non-monetary, 
component. To capture this, we assume that $D=\varphi V(x)-P_{0}$, where $\varphi \leq 1$. (To ensure that $D$ is nonnegative, we further assume that $\varphi \geq P_{0} / V(x)$.) Given this measure of damages, the seller, upon realizing the cost of performance, $C$, will breach if and only if $-D>P_{0}-C$, or if and only if $C>\varphi V(x)$. This results in excessive breach if $\varphi<1$. Anticipating the seller's breach decision, the buyer will choose $x$ to

$$
\max \int_{0}^{\varphi V(x)}\left(V(x)-P_{0}\right) f(C) d C+\int_{\varphi V(x)}^{\infty}\left(\varphi V(x)-P_{0}\right) f(C) d C-x
$$

where the first term is the return in the performance state and the second is the return in the breach state. The first-order condition defining the buyer's investment, $x_{C}$, is given by

$$
F(\varphi V(x)) V^{\prime}(x)+[1-F(\varphi V(x))] \varphi V^{\prime}(x)+(1-\varphi) V(x) f(\varphi V(x)) \varphi V^{\prime}(x)-1=0 .
$$

Note that if $\varphi=1$, the seller's breach decision is efficient (given $x$ ), and (9) reduces to $V^{\prime}(x)-1=0$, implying that $x_{C}>x^{*}$; that is, the acquirer overinvests. This reflects the standard moral hazard problem associated with expectation damages (Shavell, 1980). In other words, the buyer overinvests because he is fully insured against the risk of non-performance. At the other extreme, if $\varphi=P_{0} / V(x)$ (corresponding to $D=0$ ), the seller will breach whenever $P_{0}<C$ (i.e., whenever she would suffer a loss), and (9) reduces to $F\left(P_{0}\right) V^{\prime}-1=0$. Thus, assuming that $V(x)>P_{0}$, meaning that the buyer initially expected a profit from the transaction, the seller will breach too often, but the acquirer will invest efficiently, given the excessive probability of breach. It follows that efficient breach and investment are therefore not simultaneously attainable for any $\varphi \in\left[P_{0} / V(x), 1\right]$ under the standard expectation damage remedy. Either the buyer will overinvest, or the transaction will occur too infrequently, or both, depending on the value of $\varphi$.

\subsection{Contract Law Under Specific Performance}


In a limited set of breach of contract cases (for example, those involving land or unique goods), the court will allow a specific performance remedy rather than payment of damages. In other words, the court simply enforces the contract as written. Under this remedy, contract law becomes a variant of property law because, once the buyer purchases the entitlement to performance (promised delivery of the input), that entitlement continues to be protected by a property rule, so the seller can only cancel performance by renegotiating with the buyer. This approach eliminates the holdup problem (as the money damage remedy did), and also removes the risk of legal error from mis-measurement of the buyer's loss from non-performance, but in its place a new inefficiency emerges that mirrors the original holdup problem.

To see this, suppose, as above, that the initial price of the promised transfer is $P_{0}$, and that once the contract is made, the buyer invests $x$ in reliance on that promise. Under specific performance, however, once the seller realizes $C$, she can still cancel performance by negotiating an acceptable buy-out price from the buyer. Let that new price be $P_{1}$. The buyer will be willing to accept the buy-out rather than demanding performance if $P_{1} \geq V(x)$ for any given $x$, and the seller will only be willing to pay $P_{1}$ if $P_{1} \leq C$. Assuming that all mutually beneficial buy-outs occur according to these terms, performance will be cancelled if and only if $C \geq V(x)$, which is the efficient condition, given $x$. Thus, as was true under the property rule, the choice between performance and breach occurs efficiently under specific performance. As for the actual buy-out price, assume, as above, that it is determined by generalized Nash bargaining, yielding

$$
P_{1}=(1-\alpha) V(x)+\alpha C,
$$

where $\alpha$ is, again, a measure of the buyer's bargaining power. Note that this expression mirrors that in (4), though here, the transaction involves the seller's buying of the right not to deliver the entitlement, given that the buyer had purchased the right to delivery before investing $x$. In 
contrast, under the property rule, the buyer had to purchase the right to acquire the entitlement after investing $x$. In both cases, the condition for the buyer to end up with the entitlement is the same-namely, $V(x)>C$, which is the efficient condition. The difference between the two cases is the direction of the transfer - that is, who has to pay whom-which varies depending on who holds the legal entitlement to the input at the time that $x$ is chosen and $C$ is realized.

Now move back to the buyer's choice of $x$ in anticipation of the above outcomes. The buyer's problem is to choose $x$ to

$$
\max \int_{0}^{V(x)}\left(V(x)-P_{0}\right) f(C) d C+\int_{V(x)}^{\infty}\left(P_{1}-P_{0}\right) f(C) d C-x
$$

where the first term is the buyer's return in the performance state and the second is his return in the buy-out state. Substituting for $P_{1}$ from (10) and taking the derivative with respect to $x$ yields the first-order condition

$$
F(V(x)) V^{\prime}(x)+[1-F(V(x))](1-\alpha) V^{\prime}(x)-1=0 .
$$

Note that this yields the first-best outcome if $\alpha=1$, but results in overinvestment if $\alpha<1$ (Rogerson, 1984). Thus, as under the property rule, the buyer invests efficiently if he expects to capture all of the surplus from any cancellation bargain, but now he overinvests if he expects the seller to capture any of the gains. The overinvestment occurs here because, when $C>V(x)$, performance is inefficient, but unless $P_{1}=C$, the buyer at least partially ignores the inefficiency. This is the opposite of the inefficiency under a property rule (the holdup problem), which resulted in underinvestment when $\alpha<1$. The asymmetry reflects the opposite entitlement points in the two cases at the time the buyer invests-here it is the buyer who holds the entitlement, whereas under property law it was the seller. The inefficiency reflected in (12) is thus the mirror image of the holdup problem under a pure property rule. It is in this sense that the property rule and specific performance are variants of one another. 


\subsection{Comparison of the Three Cases}

We are now in a position to compare the three legal regimes by computing the expected gain from the transaction under each. For purposes of the comparison, we focus on those transactions where ex ante bargaining is technologically feasible, since both property and contract law are only relevant when such bargaining is possible. The benchmark is the first-best expected gain, as reflected by (1) evaluated at $x^{*}$.

First, under property law, the expected gain is

$$
W_{P}=\int_{0}^{V\left(x_{P}(\alpha)\right)}\left(V\left(x_{p}(\alpha)\right)-C\right) f(C) d C-x_{p}(\alpha) \text {. }
$$

When $\alpha=1$, this corresponds to first-best outcome, but $W_{P}$ declines as $\alpha$ falls below one, reflecting a more severe holdup problem. The expected gain under a liability rule (tort law) is given by

$$
W_{T}=\int_{0}^{V\left(x_{L}(\varphi)\right) / \varphi}\left(V\left(x_{L}(\varphi)\right)-C\right) f(C) d C-x_{L}(\varphi) .
$$

When $\varphi=1$, this also corresponds to first-best, but $W_{T}$ declines as $\varphi$ falls below one, reflecting increasing court error. Finally, the expected gain under contract law is

$$
W_{c}=\int_{0}^{\varphi V\left(x_{C}(\varphi)\right)}\left(V\left(x_{C}(\varphi)\right)-C\right) f(C) d C-x_{C}(\varphi) .
$$

Here, the first-best is generally not attainable for any value of $\varphi$ since, even in the absence of court error, there is a moral hazard problem inherent in expectation damages. However, as the probability of breach approaches zero, $x_{C} \rightarrow x^{*}$, and contract law approaches first-best because it avoids the holdup problem.

The preceding analysis suggests that the choice among the various legal regimes depends on three general factors: (i) the severity of the holdup problem, (ii) the extent to which the court 
is prone to error in measuring damages, and (iii) the likelihood that the parties will want to terminate the transaction after the initial investment is in place. In cases where the holdup problem is not severe, property law is the most efficient regime because it avoids the need for the court to become involved in pricing the transaction. Thus, in cases where preparatory investments are not important for buyers, or buyers are able to capture most of the gains from bargaining, property rules are preferred to liability rules. If, in contrast, the holdup problem is severe, then contract or tort law may be preferred to property law. If the probability of performance is high, contract law is preferred to tort law because in this case, parties can precommit to a price for the exchange, thus mitigating the holdup problem. Although the use of money damages (a liability rule) creates a risk of overinvestment by the buyer due to legal error, if the risk of breach is low, this will not cause a significant distortion. Alternatively, if the holdup problem is severe and the probability of breach is high, tort law (a pure liability rule) will be the preferred regime.

\subsection{An Example}

A simple numerical example will help to further refine the preceding delineations among the three regimes. Let the buyer's value of performance be $V(x)=\theta x^{1 / 3}$, and assume that $C$ is distributed uniformly on $[0,4]$. Also suppose that $\varphi=.77$, reflecting the court's underassessment of damages under a liability rule, whether in the context of torts or contracts. The expressions in (13), (14), and (15) can be evaluated for different values of $\alpha$ and $\theta$, where higher $\theta$ corresponds to a higher expected gain from exchange (i.e., a higher probability of an efficient transaction), and higher $\alpha$ indicates that the buyer obtains a higher share of the gains from any bargain, thus reducing inefficiency from the holdup problem. Table 1 shows the legal regime that yields the 
highest expected gain for each $(\alpha, \theta)$ combination, where $\mathrm{P}$ indicates property, $\mathrm{T}$ indicated tort (liability rule), and $\mathrm{C}$ indicates contract.

[Table 1 here]

As suggested above, property law dominates for high values of $\alpha$ regardless of $\theta$ because when the holdup problem is not severe, market transactions are the best means of achieving efficient exchange and investment (reflecting Coasian bargaining). ${ }^{10}$ However, when $\alpha$ is low, meaning the holdup problem is a significant source of inefficiency, either tort law (a pure liability rule) or contract law (a combination of property and liability rules) will be preferred. Tort law is preferred when $\theta$ is low (i.e., breach is very likely), and contract law is preferred when $\theta$ is high (i.e., breach is not very likely).

\section{Some Applications of the Analysis}

This section applies the preceding framework to some well-known cases in an effort to further illustrate its applicability. In some cases, the analysis will be used to affirm the court's ruling, and in others, to suggest that a different remedy may have been more efficient. The analysis will be framed in terms of boundaries between the various areas of law; that is, where one area shades into another around the "color wheel." The discussion is meant to be illustrative and suggestive rather than exhaustive.

\subsection{The Property-Tort Boundary}

As noted, the property-tort boundary is epitomized by the choice between property rules and liability rules, as first proposed by Calabresi and Melamed (1972). This choice is often discussed in the context of the well-known case of Boomer v. Atlantic Cement Co. ${ }^{11}$ The case

\footnotetext{
${ }^{10}$ Obviously, property law prevails for all $\alpha>.5$.

1126 N.Y.2d 219, 257 N.E.2d 870 (1970).
} 
concerned a suit brought by a group of plaintiffs seeking an injunction to shut down a neighboring cement plant because of the noise and dust that its operation produced. The case offers a prototypical example of the hypothesized transaction underlying the above model. Specifically, the factory owner (buyer) had made a substantial investment (\$45 million) in building the plant, but the external cost created by its operation (which the court put at $\$ 185,000$ ) necessitated the acquisition of the health and tranquility of neighboring residents (sellers) as an "input." The lawsuit brought by the plaintiffs therefore asked the court to shut the factory down—in effect, to "govern" this transaction by a property rule—which, if granted, would have required the factory owner to purchase the input from the plaintiffs in order to remain in operation. Instead, the court ordered the factory to pay damages, thereby allowing it to stay in operation by forcing the transaction (which is efficient) under a liability rule.

The usual interpretation of this case by economists is that the court imposed the correct remedy in opting for a liability rule over a property rule. In other words, the court properly chose to organize the transaction between the factory and the neighboring landowners under tort (nuisance) principles rather than under property (trespass) principles. In terms of the model, the decision was correct because the factory had invested a very large amount in the plant and was therefore in a position to be held up by residents in subsequent bargaining if a property rule had been used. ${ }^{12}$ (One might argue that the factory could have avoided the holdup threat if it had sought to acquire the right to pollute from the residents before investing in the plant, but that would have involved an assembly problem, to be discussed below.) Offsetting this is the risk of mis-measurement by the court of the value of the pollution rights to the residents. In this case, the very large differential between the value of the plant and the damages to victims ( $\$ 45$ million

\footnotetext{
${ }^{12}$ See, for example, Goldberg (1985). On a more general comparison of trespass and nuisance law, see Merrill (1985).
} 
and $\$ 185,000$, respectively) suggests that the transfer was probably efficient, even if the court mis-measured the damages. ${ }^{13}$ In general, however, the risk of mis-measurement needs to be weighed against the gain from avoiding the holdup threat in deciding on the proper remedy.

This point is illustrated by another well-known case in which the trade-off was probably a closer call than it was in Boomer. Spur Industries, Inc. v. Del E. Webb Development Co. ${ }^{14}$ involved a land developer who encroached on a pre-existing cattle feed lot and then sued for injunctive relief due to the foul odors emitted by the lot. The court granted the requested relief, but required the developer to compensate the feed lot for its lost profits and/or relocation costs. In essence, it allowed the developer to "buy out" the feed lot under a liability rule.

Like Boomer, this case involved the involuntary transfer of "pollution rights," though here, the forced transfer was from the "polluter" to the "victim." The different direction of the transaction arose from the court's implicit assignment of the right to pollute to the feed lot under the coming-to-the-nuisance doctrine by virtue of its having been there first. ${ }^{15}$ In terms of the model, therefore, it was the developer (buyer) not the feedlot (seller) who potentially faced the holdup threat. However, because the developer's encroachment was gradual, he probably had not committed substantial resources to developing the properties in the vicinity of the feed lot by the time that he first encountered the external cost. Thus, bargaining should have been possible between the developer and the owner of the feed lot to arrange a transfer of the right to pollute prior to the developer's having made further investments. In other words, organizing the exchange under property rather than tort principles would seem to have been possible in this case

\footnotetext{
${ }^{13}$ The total value of the factory may have been $\$ 45$ million, but the proper measure of the cost of shutting it down would have been the difference between this amount and the value of the plant and equipment in its best nonpolluting use, which presumably was not zero.

${ }^{14} 494$ P.2d 701 (Ariz. 1972).

15 The court's assignment of the right in this case illustrates the arbitrariness within the current framework of the labels victim and injurer. This reflects the reciprocal nature of externalities, as first pointed out by Coase (1960).
} 
without creating a serious holdup problem. Based on this logic, it seems that the Spur case would have been better put on the property side of the property-tort boundary. ${ }^{16}$

Another land use context that occupies the nexus between property and tort law are cases involving the assembly of land. The fundamental economic problem here, whether the assembly is for use in a private or a public project, is the threat of a holdout problem, which is a close cousin of the holdup problem. Specifically, the need for assembly creates a similar risk of inefficient land use because would-be assemblers fear that, once they have commenced acquiring properties (that is, once they have committed some resources to the project), they will be prevented from going forward because later owners, recognizing the necessity of their properties to the completion of the overall project, will have an incentive to seek artificially inflated prices. The holdout threat is thus a "numbers" problem, in contrast to the holdup threat, which can arise even in a small numbers case. ${ }^{17}$ Nonetheless, the resulting inefficiency is very similar (Miceli and Segerson, 2012a).

It has been long recognized that the holdout problem is the proper economic justification for the use of eminent domain, a form of liability rule, which compels owners to sell in return for court-awarded "just compensation" (damages). The case of Kelo v. City of New London, ${ }^{18}$ which involved the use of eminent domain to assemble land for a large scale urban redevelopment project when a few owners refused to sell, epitomized this situation. The argument for forced

\footnotetext{
${ }^{16}$ See Coleman (1988, Ch. 2, fn. 5), who makes a similar point.

${ }^{17}$ Based on this distinction, notice that the Boomer case can actually been characterized as either a holdout or a holdup problem because there were a large number of plaintiffs, all of whose consent would have been required to allow the factory to operate if an injunction (property rule) had been invoked. (Indeed, Fischel (1995b, pp. 75-77) characterized the Boomer case as involving a holdout problem). In contrast, Spur only involved two parties-a single buyer and a single seller-and so involved a pure holdup threat (albeit a small one, as I have argued).

${ }^{18} 545$ U.S. 469 (2005).
} 
transfer of land in this case was not uncontroversial, however, as the political reaction to the Kelo case demonstrated. ${ }^{19}$

In terms of the current framework, the trade-off involved in assembly problems is between the inefficiency from the holdout problem (potentially resulting in underinvestment), and the difficulty courts have in accurately measuring the opportunity cost of the taken land. Although a fair market value standard is generally used to proxy for this cost, as noted above, there is good reason to believe that this measure of compensation systematically undervalues land relative to what owners would accept in a consensual transfer owing to the existence of subjective value (Knetsch and Borcherding, 1979; Fischel, 1995a). Since courts cannot observe this value, however, it is impossible to know whether an owner who refuses an offer to buy truly values the land above the offered amount, or is strategically holding out in an effort to extract a share of the buyer's expected profit. While such a strategy is possible in any proposed transaction, it is especially problematic in an assembly context because if every owner adopted the same strategy, few such projects, no matter how valuable, would ever be completed. The use of eminent domain (a liability rule) in such cases therefore reflects the argument that, on balance, the cost of underprovision of large scale projects if organized under property law principles (i.e., requiring only consensual transactions), outweighs the risk of undercompensation of owners (and possible overprovision of these projects) if organized under tort principles. In this sense, eminent domain cases — those involving assembly_properly fall on the tort side of the propertytort boundary. In contrast, the denial of eminent domain power in cases not involving assembly (the vast majority of one-on-one property transfers), recognizes that the balance tilts in the other

\footnotetext{
${ }^{19}$ See, for example, Lopez et al. The controversy over this case, however, turned on the "public use" question—that is, whether the use of eminent domain was appropriate given that the planned use of the assembled land was largely for economic development rather than for provision of a public good. From an economic perspective, however, that issue turns out to be beside the point (see, for example, Miceli (2011b)).
} 
direction in transactions where assembly of multiple parcels is not involved, and hence, the holdout problem is absent. ${ }^{20}$

The discussion in this section shows the resemblance between nuisance and takings law in the sense that both allow forced transfers of entitlements under liability rules. ${ }^{21}$ In the current context, the justification is to prevent inefficiencies arising from either holdup or holdout problems under property rules. From this perspective, the controversy that surrounds the use of liability rules in takings cases, especially those involving transfers from one private party to another (as was true in the Kelo case), is somewhat puzzling. Why, for example, is the allowance of a "private taking" in Spur not viewed as controversially as it is in Kelo, even though we have argued that the Spur ruling is less justifiable on economic grounds? The answer likely reflects political factors that attend any exercise of constitutional powers, especially when, in the view of some, those powers are abused. In contrast, an economic perspective allows an objective assessment of the decisions in the cases based on their underlying characteristics.

\subsection{The Property-Contract Boundary}

Consider next the boundary between property and contracts. A well-known case in this vein is Peevyhouse v.Garland Coal and Mining Co., ${ }^{22}$ which involved the breach of a contractual provision calling for a mining company to perform certain restorative work on the plaintiffs' land after completing a strip mining operation. The mining company defended its decision to breach this part of the contract on the grounds that the restoration would have cost $\$ 29,000$ while only increasing the value of the land by $\$ 300$. Based on this evidence, the court allowed the breach

\footnotetext{
${ }^{20}$ One-on-one transactions can still result in inefficiencies due to bilateral monopoly, but the wide granting of takings power in such cases runs the risk of overinclusiveness (Miceli, 2011a, pp. 34-35) .

${ }^{21}$ This perspective reflects Epstein's (1985) view that takings law should mirror nuisance principles based on the argument that the government, when it acquires or regulates property, should not stand in a superior position to individual citizens when they similarly infringe on other citizens' property.

22382 P.2d 109, cert. denied, 375 U.S. 906 (Okla. 1962).
} 
and awarded the Peevyhouses $\$ 300$ in damages, a ruling that, on its face, seems efficient given the large discrepancy between the cost of the restorative work compared to its value. In this sense, the case looks a lot like Boomer.

Many observers have suggested, however, the court's use of a liability rule to allow the mining company to "buy back" the Peevyhouses' right of performance may have involved a substantial undervaluation of that right, given the likely presence of a high subjective value of the land on the part of the plaintiffs. ${ }^{23}$ In this case, the transaction involved transfer of the right to performance of the post-mining restoration, which the Peevyhouses initially held by virtue of the original contract. The court's ruling, however, allowed the mining company to acquire that right under a liability rule (i.e., without the Peevyhouse's consent) at a price set by the court. Apart from the question of whether or not the court undervalued the land, the decision to invoke a liability rule was justifiable in terms of the model only if it avoided a holdup problem that the mining company would have faced based on investments it made after agreeing to the initial contract terms, and which would have been lost if the Peevyhouses refused to give up the right to the restoration. There is no evidence that such a holdup threat existed. Thus, a better resolution would seem to have been for the court to order a specific performance remedy (a property rule), which would have required the mining company to negotiate a buy-out price on terms acceptable to the plaintiffs. In this sense, the Peevyhouse case is more like Spur than Boomer, both because of the small numbers involved, and the apparent absence of a holdup problem. It thus belonged on the property side of the property-contract boundary.

The law of contract modification, which involves renegotiations of contracts in the face of changed circumstances, provides another, perhaps less obvious, example of the propertycontract boundary. The question addressed in these cases is whether the court should enforce the

\footnotetext{
${ }^{23}$ See, for example, Cooter and Ulen (1988, pp. 320-322).
} 
originally negotiated contract terms, or renegotiated terms reflecting changed circumstances. In practice, this usually involves deciding whether to enforce an initial price $\left(P_{0}\right)$, or a modified price $\left(P_{1}\right)$. Under the traditional law of modification, the court would only enforce the new price if it was supported by "fresh consideration"—-the so-called pre-existing duty rule—but economists have argued that that rule is overly mechanical and misses the fundamental economic issue at stake in such cases (Posner, 2003, p. 100). ${ }^{24}$ In contrast, the model in this paper, particularly, the version in Section 3.5 on contract breach under specific performance, shows that the relevant issue is the severity of the holdup threat if renegotiation is allowed. Two wellknown cases will serve to illustrate the point.

In Alaska Packers' Assn. v. Domenico, ${ }^{25}$ a fishing company hired a crew of fishermen to go on a salmon fishing voyage to Alaska, but once at sea, the crew refused to work unless their previously agreed-to wage was increased. The defendant assented to the increase, but later sued to have the original wage restored, and the court agreed. In other words, the court enforced the original wage $\left(P_{0}\right)$ rather than the renegotiated wage $\left(P_{1}\right)$. The case provides a classic illustration of a holdup problem confronted by the fishing company—once at sea, the defendant faced the risk that his investment would have been lost had he not agreed to adjust the wage upward. Importantly, no change in costs had occurred to justify the higher wage; the fishermen's increased bargaining power simply reflected the absence of alternative inputs. The court's enforcement of the original agreement was therefore the correct ruling because it served to discourage such efforts to engage in purely opportunistic renegotiation.

\footnotetext{
${ }^{24}$ Also see Posner (1977) and Aivazian et al. (1984).

${ }^{25} 117$ F. $99\left(9^{\text {th }}\right.$. Cir. 1902).
} 
However, the court reached a different conclusion in the case of Goebel v. Linn, ${ }^{26}$ which for that reason is often discussed in conjunction with Alaska Packers. This case concerned a contract between an ice company and a brewery that called for the ice company to deliver ice during the summer at a pre-determined price. However, when an unusually warm winter caused the market price of ice to rise well above contract price, the ice company refused delivery unless the brewery agreed to a price increase. The brewery, fearing loss of the supply of beer that it had on-hand, agreed to the price increase, but later sought to have the original price re-instated. This time, however, the court allowed the new price to stand. Although the renegotiation potentially subjected the brewery to a holdup, as in the Alaska Packers case, the court found that here, the new price was justified by the cost increase. This conclusion is in accord with the model, which showed that if the price increase exactly reflects the increased cost of the input (that is, if $\alpha=1$ in equation (10), or $P_{1}=C$ ), then the inefficiency from the holdup problem is avoided (Miceli, 2002). In contrast, had the original price $\left(P_{0}\right)$ been enforced, similarly situated breweries would have had no incentive to take into account the possibility of fluctuations in the cost of ice when making their decisions about how much beer to brew, resulting in overinvestment. The court's decision to enforce the new price thus implemented the efficient outcome. ${ }^{27}$

It is worth noting that in both Goebel and Alaska Packers, the victims of the holdup threat presumably could have sought money damages (a liability rule) as a defense against the threatened breach, but circumstances (such as the risk that the breaching party would have been judgment-proof) apparently foreclosed that route. The court's differential treatment of the renegotiated price in the two cases nevertheless reflected a proper discrimination between a price

\footnotetext{
${ }^{26} 47$ Mich. 489, 11 N.W. 284 (1882).

${ }^{27}$ Note in contrast that application of the traditional rule in this case would have involved non-enforcement of the renegotiated price because no new consideration was offered in support of it.
} 
increase that was justified by a true rise in costs, and hence did not involve a holdup threat, and one based on a mere shift in bargaining power that did.

A final example of the property-contract boundary is the law of leases, which first developed during the agricultural economy of the middle ages, but has evolved substantially since then. ${ }^{28}$ Initially, leases were primarily viewed as conveyances of an interest in land-a form of property law. Under a conveyance, the tenant in effect became the temporary owner of the land, with the right to exclude others, including the landlord, during the term of the tenancy. In other words, the tenant essentially acquired property rule protection of his occupancy. In return, the tenant incurred an obligation to pay rent, but that obligation was independent of the landlord's obligation to grant occupancy. Accordingly, if the tenant failed to pay rent for whatever reason (if, for example, the tenant's income was subject to random fluctuations during the period prior to harvest), the landlord generally could not evict the tenant; he could only sue for non-payment. ${ }^{29}$

In terms of the model, this rule makes sense since the tenant's investment in the land, usually involving the planting of crops, would have made him especially vulnerable to a holdup threat if the landlord could have threatened to evict him during the interval between the planting and harvesting of the crops. Security of tenure (i.e., property rule enforcement of the original agreement) therefore protected tenants from the holdup problem, thereby encouraging efficient land use by the tenant. In this sense, the rule corresponds to the court's enforcement of the original price in Alaska Packers' as a way of discouraging holdups.

\footnotetext{
${ }^{28}$ See, generally, Cribbet (1975) and Friedman (1990). On the law and economics of leases, see Miceli, Sirmans, and Turnbull (2001).

${ }^{29}$ One contractual response to this problem that avoided the risk of breach by the tenant for non-payment of rent was the use of sharecropping contracts, which entitled the landlord to a fixed share of the harvest (Allen and Lueck (1993), and Eswaran and Kotwol (1985)).
} 
Over time, however, tenancy agreements were increasingly used for housing rather than agriculture. In this case, landlords rather than tenants became the primary suppliers of essential inputs, such as the continuous provision of heat, maintenance of the building, and so forth. Under the traditional law of leases as conveyances of property, however, landlords would have had little incentive to provide these inputs once a tenant took possession, and the tenant would have still owed the rent. Of course, the tenant could have sued the landlord to supply the inputs, but as Cribbet (1975, p. 206) noted, this remedy was "a frail reed for most economically pressed tenants." Thus, a rule that protected tenants' possessory interests and promoted efficient land use in the agricultural context was not well-suited to the residential context.

Eventually, the law responded to the changing nature of tenancy by reinterpreting the lease according to contract principles. This involved two important changes. First, courts found an "implied warranty of habitability," which obligated the landlord to maintain the unit in good repair (i.e., to supply the essential inputs), ${ }^{30}$ and second, this warranty and tenants' obligation to pay rent became mutually dependent. As a result, tenants now had the right to withhold rent in the event the landlord failed to supply the promised services, and correspondingly, the tenant had a legal duty to pay rent, which the landlord could enforce by exercising his legal right to eviction. Under contract principles, therefore, both parties now had legal remedies (essentially, liability rules) at their disposal in the event of breach by the other. The transformation of leases from conveyances into contracts thus created a mutuality of obligations on the part of landlords and tenants that were enforceable by court-imposed remedies that better served the fundamentally different economic character of the underlying transaction.

\subsection{The Tort-Contract Boundary}

\footnotetext{
${ }^{30}$ See, for example, Javins v. First Nat'l Realty Corp. 428 F.2d 1071 (1970).
} 
Finally, to complete the circuit around the color wheel, consider the boundary between torts and contracts. The prototypical example here is the law of products liability. ${ }^{31}$ The historical trend in this area of law over the past century has been from a rule of caveat emptor, or no liability, to strict liability; in other words, from governance by contract law to tort law. The question is whether this change can be justified on economic grounds. In terms of the current framework, the primary efficiency question concerns the transfer of the entitlement to be free from product harm—-specifically, should the consumer be allowed to transfer it to the producer voluntarily at the time of purchase, thus waiving any right to a claim for compensation later; or should it only be transferrable at the time of an accident on terms set by the court? The absence of a holdup problem in this context makes this the principal issue.

The answer depends on the ability of the two parties - the consumer and producer-to properly judge the costs and benefits of the transfer at the time of the initial purchase. An efficient transfer on purely voluntary terms - that is, with the parties themselves deciding how to allocate the costs of an accident and the court enforcing any agreement they reach—would require them to be able to accurately judge the risk of an accident, and then to write a contract that specified the specific circumstances under which the firm would compensate the consumer, and in what amount, for any losses suffered by the consumer in the event of an accident. So far, we have assumed that such transactions are feasible based on costless bargaining and complete information on the part of both parties. In the event that these assumptions are met, the contract approach makes good economic sense. In reality, however, these assumptions may not be justified, given the costs, especially on the part of consumers, of gathering and processing the necessary information to enter into efficient bargains regarding the assignment of liability for

\footnotetext{
${ }^{31}$ See, for example, Epstein (1980) and Landes and Posner (1987, Ch. 10).
} 
product accidents. Indeed, many commentators have argued that consumers systematically misperceive risk in this context. ${ }^{32}$

Note that this problem is the flip-side of legal error in assessing damages, and implies that court involvement in setting the price of exchange in the event of an accident may be more efficient than allowing the parties to do so on their own. ${ }^{33}$ In other words, a liability rule is preferred to a property rule for governing the assignment of product-related risk if consumers are not well-equipped to enter into such transactions efficiently. In the context of the model, this outcome can actually be achieved under tort law principles, based on the application of standard liability rules, or under contract principles, with the accident being treated as a breach of an implied warranty requiring payment of damages. This reasoning is consistent with the fact that modern products liability, under both the tort and contract theories, has effectively converged on a rule of strict producer liability — that is, the use of a liability rule for governing the assignment of damages. Based on the above discussion, this is the efficient governance structure in consequence of the increasing complexity of products, coupled with systematic consumer misperceptions of risk.

\section{Conclusion}

The analysis in this paper has represented an effort to describe the boundaries between the basic common law areas of property, torts, and contracts as emerging endogenously in response to differences in the economic nature of the underlying transactions that they may be

\footnotetext{
${ }^{32}$ See, for example, Spence (1977), Polinsky and Rogerson (198 ), Landes and Posner (1987, p. 281), and Viscusi (1991, pp. 64-65).

${ }^{33}$ It is interesting to note that for product failures not involving personal injury, contractual allocation of responsibility for the costs of such failure in the form of optional warranties is allowed. This possibly reflects the view that product failures not involving injuries are sufficiently familiar to consumers that contractual allocation would result in efficient decisions (Landes and Posner, 1987, p. 281).
} 
called upon to govern. This approach represents an elaboration of the classic distinction, first proposed by Calabresi and Melamed (1972), between property and tort law using the basic building blocks of property rules and liability rules. From this perspective, the fundamental unit of study is the transaction between two (or more) parties, which may entail certain imperfections, arising from unforeseen or non-contractible contingencies, and/or from the desire of one of the parties to make non-salvageable investments prior to trade. The question of interest is whether, given these imperfections, the transaction is best governed by property, tort, or contract principles.

In this framework, the defining feature of property law is the use of property rules to govern the transaction. This rule ensures that only efficient transactions occur according to Coasian bargaining, but it also potentially creates the risk of a holdup threat if one party commits resources to the transaction prior to determination of the price. The use of a liability rule can overcome this problem because it prevents parties from engaging in opportunistic bargaining after reliance investments are in place, but the offsetting cost is that inefficient transfers may be allowed if courts systematically err in setting the price. The use of a contract balances the above problems by combining property and liability rules. Under a contract, the parties negotiate a legally enforceable price before any investments are in place, thereby avoiding the holdup problem under ordinary circumstances, but the possibility of unforeseen cost increases requires the need for a legal remedy that allows the initial price to be adjusted to prevent inefficient transactions without reviving the holdup problem. This involves the use of a liability rule to govern breach of the original agreement.

The formal analysis demonstrated the circumstances under which each of these legal regimes was preferred in terms of achieving the greatest gains from trade. The discussion of the 
case law then illustrated the conclusions by examining areas of law that occupy the "boundaries" between the primary areas. The goal was not to suggest that the law mirrors exactly the prescriptions of the model. Rather, it was to propose a unifying framework that offers a coherent perspective on the role of the law in facilitating efficient economic exchange and investment. 


\section{References}

Aivazian, V., M. Trebilcock, and M. Penny (1984) "The Law of Contract Modifications: The Uncertain Quest for a Benchmark of Enforceability," Osgoode Hall Law Journal 22: 173-212.

Allen, D. and D. Lueck (1993) "Transaction Costs and the Design of Cropshare Contracts," Rand Journal of Economics 24: 78-100.

Ayres, I. and E. Talley (1995) "Solomonic Bargaining: Dividing a Legal Entitlement to Facilitate Trade," Yale Law Journal 104: 1027-1117.

Bolton, P. and M. Dewatripont (2005) Contract Theory, Cambridge, MA: MIT Press.

Calabresi, G. and A. Melamed (1972) "Property Rules, Liability Rules, and Inalienability," Harvard Law Review 85: 1089-1128.

Coleman, J. (1988) Markets, Morals, and the Law, Cambridge: Cambridge Univ. Press.

Cooter, R. and T. Ulen (1988) Law and Economics, Glenview Ill.: Scott, Foresman and Co.

Cribbet, J. (1975) Principles of the Law of Property, 2d. Ed., Mineola, N.Y.: The Foundation Press.

Epstein, R. (1985) Takings: Private Property and the Power of Eminent Domain, Cambridge, MA: Harvard Univ. Press.

(1980) Modern Products Liability Law, Westport, CT: Quorum Books.

Eswaran, M. and A. Kotwol (1985) "A Theory of Contractual Structure," American Economic Review 75: 162-177.

Fischel, W. (1995a) "The Offer/Ask Disparity and Just Compensation for Takings," International Review of Law and Economics 15: 187-203.

(1995b) Regulatory Takings: Law, Economics, and Politics, Cambridge, MA:

Harvard Univ. Press.

Friedman, M. (1990) Friedman on Leases, 3d. Edition, New York: Practicing Law Institute.

Friedmann, D. (1989) “The Efficient Breach Fallacy,” Journal of Legal Studies18: 1-24.

Goldberg, V. (1985) "Relational Exchange, Contract Law, and the Boomer Problem," Journal of Institutional and Theoretical Economics 141: 570-575.

Kaplow, L. and S. Shavell (1996) "Property Rules versus Liability Rules," Harvard Law Review 109: 713-790. 
Klein, B., R. Crawford, and A. Alchian (1978) "Vertical Integration, Appropriable Rents, and the Competitive Contracting Process," Journal of Law and Economics 21: 297-326.

Knetsch, J. and T. Borcherding (1979) "Expropriation of Private Property and the Basis for Compensation." Univ. of Toronto Law Journal 29: 237-252.

Landes, W. and R. Posner (1987) The Economic Structure of Tort Law, Cambridge, MA: Harvard Univ. Press.

Merrill, T. (1985) "Trespass, Nuisance, and the Cost of Determining Property Rights," Journal of Legal Studies 14: 13-48.

Miceli, T. (2011a) The Economic Theory of Eminent Domain: Private Property, Public Use, Cambridge: Cambridge Univ. Press.

(2011b) "Free Riders, Holdouts, and Public Use: A Tale of Two Externalities," Public Choice 148: 105-117.

(2002) "Over a Barrel: A Note on Contract Modification, Reliance, and Bankruptcy," International Review of Law and Economics 22: 41-51.

Miceli, T. and K. Segerson (2012a) "Holdups and Holdouts: What Do They Have in Common?" Economics Letters 117: 330-333.

(2012b) "Land Assembly and the Holdout Problem Under Sequential Bargaining," American Law and Economics Review 14: 372-390.

Miceli, T., C.F. Sirmans, and G. Turnbull (2001) "The Property-Contract Boundary: An Economic Analysis of Leases," American Law and Economics Review 3: 165-185.

Polinsky, A. and W. Rogerson (1983) "Products Liability, Consumer Misperceptions, and Market Power,” Bell Journal of Economics 14: 581-589.

Posner, R. (2003) Economic Analysis of Law, $6^{\text {th }}$ Edition, New York: Aspen Law \& Business. (1977) “Gratuitous Promises in the Law,” Journal of Legal Studies 6: 411-426.

Posner, R. and A. Rosenfield (1977) "Impossibility and Related Doctrines in the Law," Journal of Legal Studies 9: 71-92.

Spence, A. (1977) “Consumer Misperceptions, Product Failure and Producer Liability,” Review of Economic Studies 59: 93-108.

Ulen, T. (1984) "The Efficiency of Specific Performance: Toward a Unified Theory of Contract Remedies," Michigan Law Review 83: 341-403. 
Viscusi, W. (1991) Reforming Products Liability, Cambridge, MA: Harvard Univ. Press.

White, M. (1988) "Contract Breach and Contract Discharge Due to Impossibility," Journal of Legal Studies 17: 353-376.

Williamson, O. (1975) Markets and Hierarchies, New York: Free Press. 


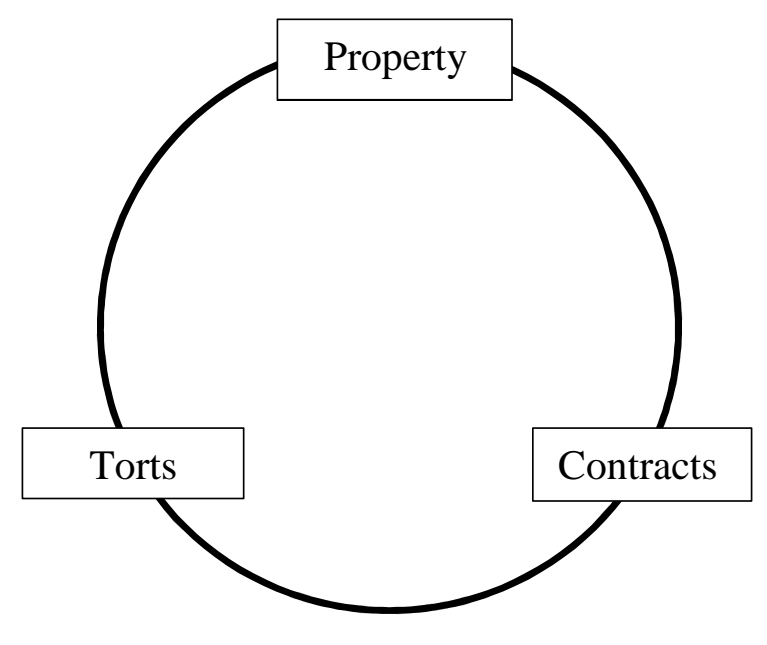

Figure 1. The "Color Wheel". 


\section{Table 1}

Comparison of the three principal legal areas, $\varphi=.77$.

\begin{tabular}{cccccccc} 
& & & & $\theta=$ & & \\
& 3.0 & 3.1 & 3.2 & 3.3 & 3.4 & 3.5 & 3.6 \\
\hline .50 & $\mathrm{P}$ & $\mathrm{P}$ & $\mathrm{P}$ & $\mathrm{P}$ & $\mathrm{P}$ & $\mathrm{P}$ & $\mathrm{P}$ \\
.45 & $\mathrm{P}$ & $\mathrm{P}$ & $\mathrm{P}$ & $\mathrm{P}$ & $\mathrm{P}$ & $\mathrm{P}$ & $\mathrm{P}$ \\
.40 & $\mathrm{P}$ & $\mathrm{P}$ & $\mathrm{P}$ & $\mathrm{P}$ & $\mathrm{P}$ & $\mathrm{P}$ & $\mathrm{C}$ \\
.35 & $\mathrm{P}$ & $\mathrm{P}$ & $\mathrm{P}$ & $\mathrm{P}$ & $\mathrm{P}$ & $\mathrm{C}$ & $\mathrm{C}$ \\
.30 & $\mathrm{~T}$ & $\mathrm{~T}$ & $\mathrm{~T}$ & $\mathrm{~T}$ & $\mathrm{~T}$ & $\mathrm{C}$ & $\mathrm{C}$ \\
.25 & $\mathrm{~T}$ & $\mathrm{~T}$ & $\mathrm{~T}$ & $\mathrm{~T}$ & $\mathrm{~T}$ & $\mathrm{C}$ & $\mathrm{C}$ \\
\hline
\end{tabular}

